\title{
Chris Mooney-Singh
}

\section{Shadow Play}

The audience sat on chairs as well as rugs and mats. The announcer addressed them in Bali-English explaining how the dalang, the puppet master would now recite mantras to warm up his voice behind the white cotton screen, lit from behind. He sought a ritual blessing from the gods. "Feel free to go backstage and look. It's our tradition," the emcee said, indicating that the audience could also get up anytime for coffee or to stretch their legs. This was his customary spiel, meant to put the audience at ease.

Margot remembered her Brisbane days studying anthropology and Murri dialects. She had attended a corroboree staged in the QPAC Concert Hall—how the audience sat politely watching jabiru crane and kangaroo dancers doing a song-cycle chant with sticks and didgeridoo. Fifteen minutes in, the singer stopped abruptly. "Hey youse blokes," he said addressing evening gowns and dress suits with velvet bowties. "What s'matter? Yer not enjoyin yer selves? Yer not gettin up for drinks n smokes?" Relief had become a flood of applause and laughter. They relaxed.

“Can we go and look behind?” Pauline asked Margot. "The man said so.”

Here was an opportunity to help her daughters bond with their new stepfather. Simon had picked up a brochure in the hotel advertising the Singapore Asian Puppetry Festival, and so they had brought the girls. Their clingy behaviour was wearing her out though, so Margot laid down her no-negotiation terms. "If Simon goes with you."

Pauline looked to Adele. Neither was happy. Why palm them off to him? "No. With you Mum," she said, just audibly through tight lips, darting a glance at the stepdad. He heard all but bit his lip.

“I'm staying put," said Margot. "I need a break. Simon knows all about these things." Her eyes looked compassionately at him while directing her words to the girls, trying to take back the blows her daughters dealt.

Pauline whined on like a mosquito and frowned. Adele was also pouting. They would have much preferred to be on this trip alone with her. The joint custody arrangement with Pierre, her ex had been working until the recent marriage with Simon. His new presence had complicated matters. A legal order 
later, Pierre was successful in getting a ruling that stated that Margot could take the girls for an overseas trip but had to return by a set date. If not, he could sell the house and use the funds for child-recovery. It was ridiculous. He was still trying to control her even though she had divorced him five years back. This trip was meant to be a honeymoon as well as a chance to retrieve the better part of her darlings' attention for an uninterrupted three months away. She also hoped the girls would begin to let Simon into their family.

"Mummy, we want you, not..." Pauline's outburst showed her highly-strung and flawed behaviour.

"Don't push it, Paul. I have the peg right here inside my pocket." Both had grown too old for baby threats to heal bad attitudes, but her tone still made Pauline hesitate. "You can't go alone. It's as simple as that," Margot concluded.

Boundaries asserted, Pauline gave in. "Alright," she snarled. They got up with Simon to see the back end of the shadow world. He was relieved.

Behind the cotton screen, the puppet master intoned mantras to coax spirits upon his tongue while pronging stick puppets into a wet, green log.

"What's that?" asked Adele pointing down at the section of trunk. At first Simon did not know, then remembered seeing the same while fruit picking near Coffs Harbour on the north coast of New South Wales.

"A banana trunk," he answered.

The girls nodded begrudgingly, not wanting to acknowledge him too much. Finally, curiosity spoke up when the puppet man lifted a painted stick figure from the squishy stem, illuminated by the lamp that gave off the scent of coconut oil.

“Why's he waving his fan about?" Adele asked again, while big sister Pauline, still pouting said nothing.

"It's not a fan," Simon whispered with backstage etiquette so as not to disturb those working hard behind the dalang - the four gamelan players gonging their hammers on xylophonic bronze. He looked closer at the vertical fan with a tree painted on it. The intricate design also showed a tiger and wild boar underneath while monkeys sat in the branches. 
"But what's it for?" asked dying-to-know Adele, noticing the Tree-of-Life fan centre screen. She was the more objective of the two. Simon remembered that epics begin with an invocation. "I think it starts the show." The Tree of Life, the fan-like Kayonan puppet appeared at the beginning and at end of a shadow play. Next came the five Pandava brothers. They would have to contend with a cast of demon enemies. Back stage gamelan musicians created the ambience.

Having warmed up, the dalang began to voice some of his hundred stock characters. This is superb. How lucky to have caught this show, Simon thought. He looked around the screen and snatched a glimpse of Margot relaxing on a rug and enjoying a free mum moment. Jealous Pauline noticed him gazing at her mother and tried to divert him. "Oh, they're just stupid cartoons," she said loudly. Eyes reacted to her rudeness. Seated parallel to the side of the white screen, the announcer squinted at the girls who had brought their sense of entitlement all the way from Australia. He was used to it.

"Sorry," whispered Simon. The troupe-manager announcer raised a calming palm and smiled patiently. He was used to working with kids on their world trips to universities and festivals. After all, they travelled to educate westerners and to earn foreign cash to support their own families back in Bali.

“They've got noses as long as witches," Pauline provoked.

“And skinny necks," Adele scoffed, following, their eyes of judgement on the flat-faced figures held up by the dalang.

“They're weird," said Pauline.

Why were they like this? Simon wondered. They've flipped from angels into she-devils. Because of me? There was a barrier between them whose name was 'Papa.' Nevertheless, the onus was on him, the dad inresidence, to win them. "Look. See how nicely they're painted."

They fidgeted and would not buy in.

Reading the situation, the announcer tried a rescue. "Girls, it's hard work cutting leather, painting a nose so noble. That's Arjuna. He's a true hero where we come from." He explained how clay and various plants were used to colour the rawhide, and how shoulder and elbow puppet hinges were made from buffalo horn. They had to be boiled down and moulded and it took a lot of puppet-maker skill.

"Yuck! Gross!" Pauline said. 
Eyes turned once more.

“Fiddle-sticks!" said Pauline, aping her mother.

“Sticks and stones," said Adele, the copy-cat.

"Bones and phones and witchetty crones", Pauline chorused.

They had veered off topic into silliness like sidewinder rockets. The girls were getting bored. "Perhaps we should go back now and sit with Mum."

The announcer forced a smile, a bit relieved. He had to keep his programme on the rails. Victory achieved, the little demonesses jumped up and ran off straight away to join their mother.

Simon felt awkward. "I'm sorry," he whispered to the troupe manager. "They're my stepdaughters, they are my wife's."

The announcer, a father in his own right, read the situation and shook his finger. "No, my friend, they are your karma now."

The truth pierced Simon like one of the puppet sticks gouging into his squishy vulnerability. "Sorry. I'd better go."

A big commotion started on the other side of the screen. Banging his toe-rattle against the puppet box, the dalang sang to a dramatic standstill. The Tree of Life was twirled away to Heaven and a tale of black shadows leapt on to the sheet of white. Now the audience was in the dalang's grasp.

3

Yudhishthira spoke in the Kawi tongue, a Sanskrit word for 'poet'. He was the noble king and epitome of the cosmic order - the dharma. Two potbelly servants attending court cracked jokes to relieve tension between scenes. A father-and-son puppet team were the play's interpreters from the classical tongue into Bali English but they, like the heroes and demons, were played by the puppet master.

\footnotetext{
“Wow! Look!"

"What's that, Dad?"
} 
They told the story of the good rajah's desire for a maha yagya, the fire-blessing for Indraprastha City and his people. Indra the god said that Yudhisthira and his Pandava brothers should first humbly enter the forest to purify themselves through meditation.

Next, sharply repeating gamelan hammers changed the mood as bulrush scenery and a pond were put in place. The dalang raised a stick fish, wiggling its tail and speaking in a sing-song voice-yo-yo, yo-yo, this way and that-yo-yo, yo-yo, until the other hand raised a stalking heron with its neck hinge preening. The shadow projected large before the audience. A little boy in the audience rushed up to touch the screen as the heron gobbled the fish, crying no! until his mother collected him and took him back, gently restraining him on her lap.

Pauline and Adele who had drifted off were roused from dozy boredom as the dalang made funny vocal sounds. "What happened?" Pauline asked. Before she could say much, the screen went blank, and a monkey popped up from below. A tiger puppet arrived, and crouched stage left, then leapt upon the simian. The dalang issued tiger-growls and monkey wails. He was a one-man animation studio. The little boy jumped up and was restrained by his mother a second time.

"So cute," said sentimental Pauline. Her better side was coming to the fore, forgetting stepdad — the tiger crouching in her life right next to Mum.

4

"Wow, son!” said old Potbelly, the commentator.

"What's up, Dad?"

That was a cue for Yudhishthira and brothers to enter. The fish returned pleading, asking for the last scene to be rewritten because she was pregnant.

"Wow!"

"Yes Dad, what?"

"The fish knows Kawi. She is a lady. Got babies in her belly."

The girls could relate and laughed. 
The heron came pleading her case as well because she had to feed her young, too. It was an ethical dilemma.

"Who will you help now, lord — fish or bird?" asked Old Potbelly.

Yudhishthira offered himself instead of the pregnant fish swimming around his ankles. But the heron could not eat a dharma lord and backed off. The dalang pulled back the puppet, blurring and enlarging the perspective of the shadow in the lamplight until heron and fish flanked the king but changed to human form moving with him off stage right. The gamelan and toe-rattle added drama.

"What happened Dad?"

"Wow! A trick from Heaven. The bird is God Vishnu and the fish, Brahma. They tried to trick our good lord Yudhishthira. You are for the people, you really a great king!”

And so, the gods rewarded Yudhisthira with a lotus flask.

"What's that, Dad?

“Amrit, son, blessed water. It can heal people and bring the dead to life."

“Oh, that's good, Dad!”

"Good brew," Simon nodded to Margot. He was trying to compensate for what had gone haywire earlier, when the girls had come flying back to the sanctuary of her cross-legged lap.

She smiled and nodded with a finger to lips gently silencing him because the looming storm of little girls was calm now and four of them had become a family.

Next, the gods instructed Yudhishthira in Kawi and the puppet cast cleared the stage except for father and son.

"What are they saying, Dad?"

"He says: 'Yudhishthira, be careful. This is special water. Look after it."'

Yudhishthira handed the precious liquid to Bhima, one of his brothers, for safe keeping. In turn, Bhima passed it to his half-demon son Ghatotkatcha, the super-wrestling giant rakshasa who was unpredictable and wild. The scenery changed to mountain outlines. Flying high above the frozen snowline Ghatotkatcha 
dropped the lotus bottle, bringing to life the demons inside. Soon, the land of snow was rumbling and boiling, threatening the earth, intensified by gamelan gongs and hand drums.

“Ah, global warming. A good comment," Simon said. "The melting of glaciers. This puppet man lives in the real world."

Some insight there, she also thought, admiring her new husband.

Of course, a tale must turn bad to turn out well in the end, Yudhishthira and the Pandavas arrived to handle with care the bad- boy, hothead demons.

The servant commentators now introduced the ways of Balinese trolls. "Our rakshasa brothers after a thousand years are free at last. See them shooting fire missiles. Good! Arrows ping! ping! ping! at the Pandavas."

Two demons did a silly dance, and, in conclusion, clonked heads, knocking each other out. Almost immediately, they recovered, roaring with belly laughter. The lead demon started doing push-ups working hard, then slow-leaked a fart. Pauline and Adele thought this hilarious and squealed with pleasure.

"Shoosh you two," Margot said, smiling.

"Sorry for my perfume, everybody," said the demon, breaking the fourth wall worthy of Artaud and Brecht. The audience also tittered, some guffawed, indicating that these ogres were endearing and not stockin-trade bad asses.

The battle raged with earthy interludes and dances by the duo.

Next, the boss rakshasa launched a fire arrow, and Yudhishthira put it out with water warfare. Arjuna challenged a rakshasa to fight to the death, sending an arrow through the demon's heart. The battle came to a Balinese standoff until demon number two conjured a Naga dragon. Yudhishthira found a way to stop it too.

Then Old Potbelly, the servant commentator made a fresh appearance. "Wow!" he said and "Wow!" then one more "Wow!” Then, "Nno, nno, ne-nno, nno”, he sing-songed.

Pauline imitated, and Adele copied her, getting a glare from Margot. She looked to her simple Simon for support, but then thought better of enlisting his aid. She longed to share the burden of parenting, hoping he 
would grow into the role sooner than later. He was younger than her and still was inexperienced handling children, despite his earnestness. This was her third marriage. Two husbands had left her ignominiously for other women. Thus, she carried in her the demons of self-failure and the sting of wagging tongues, having rushed into another marriage with someone seven years her junior.

"Now, what did I say?" she snapped at the girls, feeling pressure.

\section{5}

The demon headman, Prashchinti, assumed into his body a thousand demons to finish off the Pandavas. He grew immense, filling the shadow screen to push back the Pandavas. Yudhishthira knew if his brothers were killed the ceremonies for Indraprastha City and his people would not proceed.

"You call Shiva, Lord," Old Potbelly, the servant commentator counseled. Then young Potbelly came out of hiding. "What happened, Dad?"

"Prashchinti demon swallowed all the rakshasas. Our Lord has lost his heart. He must pray to Shiva."

Yudhishthira intoned and Shiva spoke up in Kawi.

Old Potbelly translated. "Yudhishthira, this your fault. Why give the special water to Bhima who pass it to Ghatotkacha? Young guys can't hold sacred things. Like tigress milk. Too strong, it melts through any dish, even a gold one."

Yudhishthira was getting more depressed.

Old Potbelly’s Shiva translation continued. “'Ok, don’t worry. I will help. This weapon comes from Hell. I got it back from Yama. Here." Shiva handed it over.

Weaponised, Yudhisthira stood before Prashchinti, the demon king. They charged at each other, again and again. Atomically armed by Shiva, god of destruction, Yudhishthira now had the power of ten thousand storms at his disposal. With every lunge the mountain ranges shifted, with every thrust the three worlds shook and quivered, with every clash a rakshasa fell dead, split off from Prashchinti like a shard. Yudhishthira shot the weapons from his bow until each dead rakshasa piled up and the field of battle was silent. 
"Wow!” said Potbelly. "Yes, the demon body becomes a mountain again."

"I think our ceremony will be save, son."

"Yes, Dad. I think our story stop."

The characters left and now the Tree of Life, the Kayonan shadow puppet, was shown in the centre of the screen signaling the play was over. The dalang sought customary forgiveness just in case he had hurt anyone's feelings or got things wrong, an insurance policy to ensure good karma. The gamelan played on in the background and the audience whooped and clapped.

6

"Wow!" mimicked Simon. "I think the story is done, Mum."

"Well, this one at least," she murmured.

"What do you mean?" he asked. Margot kept a lot to herself. He was still getting used to that.

Oh dear, she thought. The tropical heat in this outdoor park seemed suddenly oppressive and she did not want to risk further disjuncture. Instead, Margot smiled, hiding her apprehensions in the darkness, and snuggled up close. At least, the girls were the only puppets nodding in her lap now, subdued by travel tiredness, droned to sleep by the gamelan.

Their little event had arrived at its moment of calm. She relaxed a throbbing head against her husband's heartbeat, not knowing if she could endure more stopover standoffs like this, staged by sour children. She inwardly begged the god of honeymoons to rewrite the script, if not with a happy ending, then at least with a fresh-start chapter of her broken family saga. 